\title{
DESMONTANDO AL AUTOR: IRONÍA, PARODIA Y SÁTIRA EN LA NARRATIVA Y EL CINE AUTOFICCIONALES ${ }^{1}$
}

\author{
Ana CASAS \\ Universidad de Alcalá
}

\section{Introducción}

$\mathrm{H}$ ay un cierto consenso en concebir la autoficción como un tipo de narración paradójica, en la medida en que infringe las convenciones genéricas que organizan el relato: presenta elementos que orientan la recepción hacia la lectura autobiográfica, junto con otros que la orientan hacia la ficción. Mientras los primeros intensifican la sensación de referencialidad (habitualmente la homonimia entre autor, narrador y personaje, así como la extraordinaria coincidencia de rasgos caracterizadores entre el personaje y el autor empírico), los segundos invitan al distanciamiento entre el autor y su proyección textual. Sus objetivos coinciden, pues, con algunos de los rasgos que Linda Hutcheon (1988: 26) destaca a propósito de la literatura posmoderna en general, ya que el discurso eminentemente paródico de la Posmodernidad permite combinar la repetición (de formas, géneros, temas) con la distancia crítica. En el caso de los textos autoficcionales se subvierten determinados códigos conocidos por el receptor (la relación autor-obra y sus vínculos con el referente), pero ello se hace, de forma paradójica, desde la continuidad de dichos códigos (ya que, a pesar de la revisión paródica del discurso autobiográfico, la referencialidad del yo persiste en cierto sentido) ${ }^{2}$.

De este modo, las prácticas autoconscientes de la autoficción cuestionan nociones ingenuas en torno a la representación del autor, en especial la unidad del sujeto (en la vertiente personal e identitaria del yo) y la originalidad del artista (en la vertiente creativa del yo). En ambos casos, la conclusión suele ser el fracaso de ambas nociones: la unidad del sujeto no es trasladable al papel (o a

\footnotetext{
${ }^{1}$ Este trabajo forma parte del proyecto «Figuraciones del yo y representación autoficcional en narrativa, cine, teatro y novela gráfica en el marco de la teoría de los géneros», financiado por el Subprograma Ramón y Cajal (MICINN-RYC) 2011. De igual modo se enmarca en el Proyecto del Plan Nacional «La autoficción hispánica. Perspectivas interdisciplinarias y transmediales. 1980-2013» (FFI2013-40918-P), financiado por el Ministerio de Economía y Competitividad.

${ }^{2}$ Desde que Serge Doubrovsky acuñara el término «autoficción» en 1977, la bibliografía con relación a este concepto no ha dejado de crecer. Puede leerse una síntesis de las diversas vías por las que ha transcurrido la teoría en torno al fenómeno autoficcional en Casas (2012: 9-33).
} 
la pantalla), simplemente porque no existe o no es aprehensible -como han demostrado el Psicoanálisis y la Deconstrucción-; y lo mismo ocurre con respecto a la originalidad del artista: ligada a una visión romántica del autor, también se desvela una falacia. Como anota Quílez Esteve en un trabajo sobre el documental performativo de marcado carácter autoficcional,

el yo que se inscribe en los relatos posmodernos escritos y/o filmados en primera persona -bien sean autobiografías, diarios íntimos o memorias familiares- ha dejado de esconder sus fisuras, su inestabilidad, su hibridación. Presentándose como persona y personaje, como realidad y ficción, como original y copia, la lectura del mundo -y de sí mismo- que lleva a cabo el autor -que es también narrador y personaje- a lo largo de este tipo de obras no puede ser más que tentativa y, a menudo [...] autorreflexiva e irónica. (2009: 117)

\section{Formas del humor}

El humor es, en efecto, una de esas estrategias autoconscientes que rompen la transparencia del relato y dinamitan el discurso referencial que, inicialmente y en apariencia, la autoficción propone. Implica un modo de interrogarse sobre la identidad, pero quitándole solemnidad o dogmatismo al proceso introspectivo, al tiempo que expresa un irrenunciable compromiso con el propio arte. Este aspecto, pensamos, no ha sido suficientemente abordado por los estudios en torno a la autoficción, más preocupados por las manifestaciones «serias» del fenómeno y por discernir los elementos de hibridación y ambigüedad, y sus evidentes consecuencias para la recepción lectora ${ }^{3}$. Pero, aunque predominan los trabajos que entienden la autoficción como una modalidad de la escritura del yo erigida sobre un eje básicamente referencial - pese a las eventuales distorsiones ficcionales-, aquí vamos a interesarnos, en cambio, en la autoficción como la expresión de un rechazo -o cuanto menos de una actitud de perplejidad- ante la supuesta factualidad del autor: ello se logra, en los textos que van a ser objeto de este estudio, gracias a extremar determinados mecanismos disruptivos y paradójicos, como los recursos transgresivos de la ficción (metalepsis, mise en abyme) y, de manera muy especial, las diversas formas del humor.

\section{Ironía}

La primera de esas formas de las que vamos a ocuparnos es la ironía, partiendo de la definición que ofrece Pere Ballart en su libro Eironeia (1994). Como categoría que se caracteriza esencialmente por abrir una vía de reflexión en torno a la realidad y lo que ésta contiene -el autor incluido-, la ironía puede entenderse como un juego intelectual constituido, como mínimo, por estos seis

\footnotetext{
${ }^{3}$ No entendemos «seriedad» en el sentido que le da Marie Darrieussecq en su conocido artículo de 1996. La escritora y crítica francesa pone el acento en el estatuto radicalmente ambiguo de la autoficción, «un texto indecidible en su totalidad», en el que se lleva a cabo una «ficcionalización de lo factual» y una «factualización de lo ficticio». Desde esta óptica, Darrieussecq (1996: 81) entiende la autoficción como «una práctica de escritura ilocutivamente no comprometida o -si ser serio es ser "ilocutivamente comprometido"- una práctica de escritura no seria...». Pese a ello, la crítica se ha ocupado en demasiadas ocasiones en tratar de determinar, a través del estudio de los indicios paratextuales y peritextuales, hasta qué punto una obra es más o menos fiel con respecto a una vida, o hasta qué punto la proyección ficcional del autor hace justicia a la persona real. Sólo en fecha reciente, algunas voces, como las de Premat (2009) y Pozuelo Yvancos (2010), se han interesado, en cambio, por los dispositivos irónicos que separan el yo figurado del yo real, liberando la autoficción de los amarres de lo autobiográfico.
} 
ingredientes (Ballart, 1994: 309-324): 1) su presencia bien en el nivel verbal -ironía discursiva-, bien en el nivel de los hechos -ironía situacional-; 2) la inclusión de diversos valores argumentativos, de cuyo contraste surge la ambigüedad irónica; 3) el fingimiento o sinceridad incompleta, ya que las verdaderas opiniones (de los personajes o del narrador) aparecen disimuladas u ocultas; 4) la existencia de una estructura comunicativa específica, basada en una doble codificación y una doble descodificación, en la medida en que «sus destinatarios pueden ser los lectores que ingenuamente acepten los enunciados literales o bien aquellos que decidan trascenderlos en busca de una lectura en clave irónica» (Ballart, 1994: 319-320); 5) el interés por generar una determinada emoción en el receptor (que puede ir de la hilaridad a la compasión o animadversión hacia algún personaje o situación, etc.); y, 6) desde el punto de vista de la significación estética, el alejamiento de lo literal, al cuestionar las reglas de la armonía con las que teóricamente debe funcionar el universo artístico.

La vertiente humorística de la ironía recorre, en efecto, un buen número de textos autoficcionales en los que es posible discernir los elementos que acabamos de enumerar. Así, por ejemplo, la ironía discursiva que se extiende desde los paratextos de Los hechos (1988), de Philip Roth, al conjunto de la obra, un supuesto relato autobiográfico cuyo propósito es narrar la infancia, adolescencia y juventud del autor. La carta-prólogo que Philip Roth dirige a un tal Zuckerman, y la carta-epílogo, en este caso de Zuckerman a Roth, nos obligan a volver sobre el texto, que se encuentra entre ambas cartas, y reevaluar lo narrado: la promesa de veracidad de la carta-prólogo -en la que Roth asegura querer «reconstruirse», «poseer la vida otra vez» después de la experiencia traumática de haber padecido un cáncer- la contradice el propio autor, al negar en este mismo prólogo la posibilidad de reconstruir los hechos sin que intervenga la imaginación o sin que éstos se subordinen al momento presente. Y si el lector familiarizado con la obra de Philip Roth albergaba dudas a propósito del destinatario de la carta, el epílogo va a corroborar sus sospechas cuando Zuckerman revele -metalépticamente- su naturaleza ficcional (se trata, en efecto, de un personaje recurrente en las novelas de Roth, que, además, asimila buena parte de sus características, como los orígenes judíos o su profesión de docente y escritor). En consecuencia, un personaje de ficción es el encargado último de cuestionar la autenticidad de los acontecimientos relatados al constatar la inevitable ficcionalización que implica todo enfoque autobiográfico. De este contraste de valores argumentativos - como diría Ballart- se deriva la ambigüedad irónica. Irónicamente también, Zuckerman pone en entredicho la sinceridad del autor, al que acusa de ocultar aspectos clave de su personalidad, mostrar su lado más amable o inhibirse ante determinadas cuestiones. A través de Zuckerman, en definitiva, se cuela el autor implícito desautorizando al Roth-narrador. De este modo, la lectura del receptor es doble: por una parte, puede aceptar el autobiografismo de los hechos narrados -tal y como, en el prólogo, el autor le pide que haga, y también como sugieren las marcas genéricas diseminadas en el relato propiamente dicho-; pero, por otra parte, se ve impelido a desconfiar de esos mismos hechos, que se situarían -como se indica en el epílogo- al mismo nivel que cualquier texto de ficción. Esta lectura en clave irónica de la obra -y llegamos al último de los 
puntos que señala Ballart- descansa, en gran medida, en el cuestionamiento de las reglas y convenciones del relato autobiográfico: «Me dices en tu carta -leemos en el epílogo de Zuckermanque este libro te parece la primera cosa que has escrito "inconscientemente". ¿Con ello quieres decir que Los hechos es una obra de ficción inconsciente? ¿No percibes las artimañas propias de la ficción que en ella hay? Ten en cuenta las exclusiones, el carácter selectivo de lo que escribes, la propia postura de quien afronta los hechos. ¿Es verdaderamente inconsciente toda esta manipulación, o sólo pretende ser inconsciente?» (Roth, 1988: 214). La ironía consiste, por lo tanto, en leer la obra como una autobiografía y una novela a la vez, o como ninguna de las dos, al menos no en un sentido convencional ${ }^{4}$.

En literatura no faltan muestras del empleo de la ironía como estrategia del discurso autoficcional: en la narrativa en español, baste con recordar la obra de Enrique Vila-Matas, César Aira o Juan Antonio Masoliver Ródenas, que, haciendo uso de estilos muy distintos, ironizan sobre diversos aspectos de sus biografías y, muy especialmente, sobre la condición del escritor. En París no se acaba nunca (2003), uno de los relatos de Vila-Matas, el juego autoficcional se hace evidente gracias a la revisión irónica de los años parisinos del autor, cuando éste era un joven escritor todavía inédito y se esforzaba por parecerse -en lo personal y en lo artístico- a Ernest Hemigway, aunque, «a diferencia de Hemingway -recordará-, que fue allí "muy pobre y muy feliz”, yo fui muy pobre y muy infeliz» (Vila-Matas, 2003: 10); en El congreso de literatura (1997), un científico chiflado, que oculta su verdadera identidad bajo la máscara del escritor César Aira, trata de clonar a Carlos Fuentes y generar una estirpe de genios que inunde el planeta, obteniendo, por cierto, pésimos resultados; Masoliver Ródenas acude al diario bastardo para reelaborar su trayectoria vital, sentimental y artística como el proceso de una búsqueda, evitando la nostalgia y, al contrario, desacralizando a través del humor los grandes asuntos de la existencia, como el amor, el paso del tiempo, la amistad o el arte ${ }^{5}$. Son sólo algunos ejemplos en los que abundan homenajes respetuosos mezclados con giros irónicos, de modo que se produce lo que Linda Hutcheon denomina «ironía paródica». Un recurso que permite reactualizar las convenciones y que nos adentra en el terreno de la parodia intertexual, otra estrategia autoconsciente, como la ironía, que en este caso implica una relación dialógica entre la identificación y la distancia entre el texto y los diversos subtextos, pero que sobre todo persigue activar la conciencia del lector con respecto a dicho diálogo (Hutcheon 1985: 31).

Este último punto es de especial importancia si advertimos la clase de receptor que la autoficción demanda: como construcción compleja que implica distintas formas de codificar la

\footnotetext{
${ }^{4}$ Pozuelo Yvancos (2005: 207-208) concluye su interpretación de Los hechos del siguiente modo: «la única verdad posible para un novelista son sus personajes y cuando él intenta ser otra cosa no consigue sino suplantarlos, personificarse en un nuevo personaje con una retórica ficcional que parece más auténtica pero que no lo es, por eso mismo es un personaje de ficción el que lo reprocha. La literatura juzga los hechos y no ve en ellos nada distinto a sí misma, quizá porque la lección sea que la escritura no puede elidir la ficcionalización inherente a su propia construcción».

${ }^{5}$ Especialmente en su trilogía Retiro lo escrito (1988), Beatriz Miami (1991) y La puerta del inglés (2001), así como en su última novela El ciego en la ventana (2014).
} 
experiencia del yo, la descodificación de la obra ficcional por parte del receptor requiere que éste despliegue estrategias igualmente complejas. Sus conocimientos previos con relación a los códigos empleados - pertenecientes a los diversos discursos convocados, autobiográfico y ficcional- resultan esenciales para llevar a cabo una correcta recepción de la obra. De otro modo, la lectura se vería empobrecida (el texto sería interpretado como una autobiografía o una ficción), al no apreciarse el juego co-participativo que la obra propone. En este sentido, la exigencia posmoderna de un receptor precavido y suspicaz también parece ser una de las condiciones de la autoficción a tener en cuenta.

\section{Parodia}

En esta relación dialógica cobra especial relevancia el empleo de la parodia, que, como es sabido, puede consistir en una imitación burlesca de textos, géneros o formas (aunque, como ocurre con la ironía, no tiene por qué ser siempre cómica). En su manifestación humorística, que es la que nos interesa ahora, y en el marco de la autoficción, subvierte determinados códigos y convenciones que caracterizan el discurso autobiográfico rebajándolos, como hace Philip Roth al conferirle autoridad a un personaje de ficción para que enjuicie la obra que se ofrece al lector, o como hacen Enrique Vila-Matas, César Aira o Juan Antonio Masoliver Ródenas, contrastando irónicamente la experiencia vital del narrador con la proyectada por Ernest Hemingway en París era una fiesta (VilaMatas), acudiendo a la ciencia-ficción de serie B en escenas como aquella en la que enormes gusanos azules invaden Mérida, tras producirse un error en la clonación de la célula de Carlos Fuentes (Aira), o construyendo un falso diario, en el que confluyen todo tipo de géneros y modalidades textuales: narraciones, poemas, aforismos, etc., algunos serios y otros deliberadamente humorísticos e incluso grotescos (Masoliver Ródenas).

«La parodia posmoderna - no obstante- no destruye su hipotexto, ni lo sustituye, ni aun menos lo supera, sino que actúa junto a él, sin que se los pueda separar en ningún momento, aunque se sea consciente de la distinción entre ambos». Desde esa perspectiva lúdica y relativista, que es la que subraya Juan Carlos Pueo (2002: 45-46) en esta cita, determinadas obras exploran la dimensión humorística, abiertamente paródica, de la autoficción que descansa en el diálogo intertextual. Es el caso, ciñéndonos ahora al cine, de Caro diario (1993) y Aprile (1998) de Nanni Moretti; Ma femme est une actrice (2001) de Yvann Attal; Il est plus facile pour un chameau (2003) y Actrices (2007) de Valeria Bruni-Tedeschi; Adaptation (2002) de Spike Jonze (con guion de Charlie Kaufman); Synecdoque, New York (2008) de Charlie Kaufman; o muchas de las películas de Woody Allen, por no mencionar los documentales performativos de Alan Berliner, Avi Mograbi o Ross McElwee. Todas ellas imitan distintos géneros o formas con el objeto de cuestionarlos y, al mismo tiempo, renovarlos. En el caso de Moretti, por ejemplo, el molde del diario personal apuntaría a una referencialidad que se agudiza gracias a la homonimia entre las diversas instancias del acto creativo: el guionista, el director y el actor coinciden en la figura y el nombre de Nanni Moretti. A ello hay que añadir el tono confesional adoptado en ambos films -potenciado por la voz en off del narrador-, así como los diversos elementos de orden privado que devienen centrales en los dos relatos: la 
experiencia de la enfermedad, en Caro diario, y la de la paternidad, en Aprile. Las opiniones políticas del autor -sus reflexiones en torno a la realidad del momento- adquieren, de igual modo, un marcado protagonismo. La sensación de que estamos ante una obra que tiene mucho de autobiográfica se intensifica también con la inclusión de material documental, como la grabación de una de las sesiones de quimioterapia a las que se sometió Moretti y que se inserta en la última de las tres partes de Caro diario. No obstante, el discurso referencial se ve vulnerado por distintos elementos, algunos de ellos de gran efecto distorsionador: en primer lugar, el hecho de que estemos ante un relato guionizado resta inmediatez al diario; en segundo lugar, el uso de diversas estrategias de la ficción, como la metalepsis, quiebra la homogeneidad de la obra (en Caro diario, en varios momentos el narrador extradiegético se cuela en la diégesis y, en otras ocasiones, en su rol de personaje, se dirige directamente al espectador); por último, el humor y la presencia de situaciones inverosímiles, incluso absurdas, está en la base de la parodia, como el encuentro «casual», en Caro diario, con Jennifer Beals, la actriz protagonista de Flash Dance, y la conversación delirante que Moretti entabla con ella a propósito de sus zapatos y de la traducción italiana de la expresión «pissed off $»^{6}$. El diálogo intertextual acentúa, pues, la vis cómica del film: la evocación no sólo de Flash Dance, también de las películas de Silvana Mangano, en las que la actriz aparece bailando, o los musicales de Hollywood, son la expresión ridícula del deseo sincero de Nanni Moretti de hacer un cine portador de valores positivos o liberadores que aúne subjetividad y compromiso.

La intertextualidad paródica se expresa, en consecuencia, fagocitando formas y géneros diversos, pero también a través de la alusión a textos concretos (Flash Dance, Heat, Stranger Days, etc., en las películas de Moretti), y de la reescritura hipertextual: Stardust Memories (1980), de Woody Allen, reescribe 8 1/2 (1963), de Federico Fellini; Adaptation (2002), de Spike Jonze, el libro El ladrón de orquídeas (1998), de Susan Orlean; Il est plus facile pour un chameau (2003), de Valeria Bruni-Tedeschi, la parábola bíblica del camello y la aguja (Mateo 19:24), etc. Son relatos que usan (y abusan de) las convenciones que extraen de sus hipotextos, poniéndolas en evidencia y añadiendo un comentario irónico y crítico con relación a determinadas prácticas narrativas. La ironía, no obstante, afecta también al hipertexto, que finalmente resulta tan parodiable como el hipotexto parodiado, ya que, como apunta Juan Carlos Pueo (2002: 89), «la ironía de la parodia no se dirige tanto hacia un hipotexto concreto como hacia la propia textualidad». Supone -insiste Pueo (2002: 90) - «una conciencia de la "textimonialidad" de la obra de arte por cuanto pone al descubierto no sólo sus mecanismos, sino su indeterminación respecto a la verificabilidad o falsabilidad de sus presupuestos».

\footnotetext{
${ }^{6}$ En este sentido Caro diario respetaría la condición sine qua non de la autoficción cinematográfica, según el esquema de Herrera Zamudio (2007) -tomado a su vez de la tesis de Colonna (1989)-: por un lado, el protocolo de identidad haría coincidir autor (identificado con el guionista y el director) y personaje, de modo que ambos compartirían nombre e imagen; por el otro lado, el protocolo modal afirmaría la ficcionalidad de la obra a través de sus rasgos sintácticos relativos al montaje y la escenificación (las palabras y deseos de Moretti, como en la escena referida, se convierten en «realidad»), sus rasgos semánticos (inverosimilitudes, rupturas en la transpareencia del relato, como la metalepsis y la mise en abyme) y sus rasgos pragmáticos (la obra imita un acto verbal, en este caso el diario, con el objeto de transgredirlo a través de la ficción).
} 


\section{Ana Casas}

Adaptation servirá para ilustrar algunas de estas ideas. La protagonizan los gemelos Charlie y Donald Kaufman, cuyos nombres coinciden - uno de ellos íntegramente- con el del guionista del film ${ }^{7}$, encarnados ambos por el actor Nicolas Cage. Caracterizado con algunos rasgos del propio Kaufman (pelo rizado, estilo desenfadado en el vestir), Charlie - un tipo solitario, hipocondríaco, que no tiene éxito con las mujeres, y que se dedica a escribir guiones de cine- exhibe una personalidad completamente opuesta a la de Donald, su extrovertido hermano. A través de ellos -y del contraste entre ambos- el Kaufman-real ironiza sobre su condición de creador sin soslayar el juego metaficcional: la tormentosa adaptación del libro de Susan Orlean, que Charlie (personaje) debe acometer para la productora que lo ha contratado, es la «excusa» que le sirve para desplegar una divertida - pero no por ello menos profunda- reflexión acerca del arte de componer historias. Eminentemente paródica, Adaptation recoge tres normas del cine comercial -santificadas por el autor de métodos de escritura, Robert McKee-: no utilizar la voz en off, no escoger como protagonista a un personaje sin deseos e introducir, en cambio, conflictos y crisis (los famosos puntos de giro) que hagan avanzar la historia. Eso es lo que McKee (personaje) explica a sus alumnos del curso de guion, entre los que se encuentra un desesperado Charlie, buscando una salida a su bloqueo creativo. Sin embargo, la película que nosotros estamos viendo -producto del guion del personaje Charlie Kaufman- presenta una voz en off, un héroe sin deseos (el propio Charlie) y defiende la idea de que en la ficción -como en la vida real- no tiene por qué ocurrir nada extraordinario. Un planteamiento que también acaba siendo desmontado cuando la necesidad de terminar el guion resulta más imperiosa que ir contra el cliché, revisar el canon o ser original. Así, el desenlace acaba incluyendo todo tipo de lugares comunes del cine de acción: persecuciones, sexo, muertes dramáticas y hasta un Deus ex machina que precipita la resolución de la historia. De este modo, el objeto resultante de la «adaptación» llevada a cabo por Charlie Kaufman (personaje), es decir, la película que está pasando ante nuestros ojos y que parodia tanto los subtextos «dignos» de ser imitados (el libro de Susan Orlean) como los subtextos «degradantes» (las películas de acción al más puro estilo comercial), se transforma a su vez en objeto de parodia, en la medida en que ésta, «dirigida en principio hacia otros hipotextos, acaba por mirarse a sí misma en su propio espejo y por encontrarse los mismos rasgos que ella misma ha convocado» (Pueo, 2002: 115). Los límites entre mundo «real»-la historia del guionista que finalmente logra superar su bloqueo- y mundo «representado»-la materialización del guion de Charlie- acaban por disolverse en una obra que niega toda referencialidad -así lo ponen de manifiesto las inverosimilitudes e hipérboles de la historia o el humor desenfrenado- y que, en consecuencia, afirma su textualidad por encima de todas las cosas.

Y, no obstante, como ocurre en los ejemplos de Moretti, bajo la parodia se esconde una reflexión fundamental: si en Caro diario y Aprile se entrecruzan significativamente la labor del creador con la trayectoria vital del hombre, en el film de Kaufman la adaptación no es sólo

\footnotetext{
${ }^{7}$ Aunque el juego de las duplicidades se inicia ya en los créditos de la película, al figurar como guionistas de Adaptation Charlie Kaufman y Donald Kaufman.
} 
cinematográfica (la transformación de un libro en película), sino que también es vital, pues el personaje, durante todo su proceso creativo, trata de buscar una verdad (precaria) a su existencia, y lo hace a través del arte. Así, Charlie «se adapta» a las situaciones -nuevas, difíciles, hasta incomprensibles- que le van surgiendo al paso, mientras se enfrenta a su bloqueo y a sus propias limitaciones personales (Maldera, 2010): no sólo logra acabar su guion -aunque haciendo importantes concesiones que lo apartan de la idea de obra perfecta que se había fijado de antemano-, sino que a lo largo de su escritura aprende algo no menos importante: apreciar a su hermano, disfrutar del momento presente, aprovechar la vida, no renunciar al amor, etc. Su feliz reencuentro con Amelia, al final de la película -parodia del «happy end» de la comedia romántica hollywoodiense - funciona como una metáfora -aunque rebajada y antitrascendental- de cómo el artista -todo artista- es capaz de liberarse en lo artístico y en lo personal a través de la creación.

\section{Sátira}

La crítica que implica la parodia deriva por momentos en la sátira, una forma de humor que esconde un juicio negativo (Hutcheon, 1985: 49), tal y como puede observarse en el film de JonzeKaufman, donde se satiriza el proceso de adaptación, desbaratando la idea de fidelidad que se presupone a ésta: el guion de Charlie prosigue, en efecto, después del final de la novela, al explorar la relación sentimental -ausente en el libro- entre Susan Orlean y John Laroche, además de «desvelar» la dependencia de estos dos personajes de la droga que extraen de las orquídeas. Pero Adaptation satiriza sobre todo las pretensiones de aquellos que tratan de hacer una obra perfecta: intensa, transcendental y única, capaz de dotar de sentido a la existencia de sus creadores y, de paso, de sus receptores.

En el centro de la crítica de Adaptation, como de buena parte de los textos aludidos, están determinadas asunciones subyacentes a los conceptos tradicionales de autor y texto, ya que estos relatos cuestionan la autoridad de cualquier obra de arte, incluida la de contenido autobiográfico (de ahí el empleo, a veces masivo, del juego intertextual), así como la propia figura del autor, despojada de cualquier aura especial: tanto Moretti, Allen o Kaufman, como Roth, Vila-Matas, Aira o Masoliver Ródenas se autorrepresentan como tipos inseguros, ridículos en algunos casos, con baja autoestima o víctimas de su ego de artista. Como señala Natalia Vara (2014: 221) a propósito de París no se acaba nunca, «esta irónica autocrítica permite que el lector comprenda que, más allá de [la] existencia real [de los autores encarnados en personajes] [sus] personalidades son más fruto de una construcción ficcional llevada a cabo a propósito y en la que resulta imposible diferenciar lo natural de lo elaborado artísticamente». La sátira se opone, por lo tanto, a toda clase de didactismo (Beltrán, 2002: 258), incluido el que concierne al autor (a la idea que nos hacemos de él), así como de todo cuanto lo rodea. Para ello recurre a la tipificación, es decir, en lugar de elaborar un carácter que dote al personaje de una psicología compleja, construye un tipo a partir de unos pocos rasgos (Beltrán, 2002: 259). Surge así la figura del autor que, lejos de poseer una referencialidad que señale a la persona real, carece de identidad: queda reducido, al contrario, a un tipo que, por sus rasgos $-\mathrm{a}$ 


\section{Ana Casas}

menudo ridículos, caricaturescos- se opone a la imagen idealizada de la que tradicionalmente ha sido objeto el artista, una imagen en el fondo tan tipificada como esta otra que ahora se nos muestra.

Por fin, nada escapa a la mirada satírica, que también se vierte sobre todo lo que circunda el mundo del autor: así, los planteamientos sociales, y hasta políticos, de Moretti a través de la burla de las instituciones que mantienen la ciudad de Roma en un preocupante abandono, los hábitos de la sociedad de consumo (la tiranía del hijo único en la isla de Salina o la vacuidad de los jóvenes en Stromboli), el horrible peso de la burocracia, en Caro diario; la visión grotesca de los productores, los críticos, incluso el público en buena parte del cine de Woody Allen; o el retrato despiadado del mundillo universitario, cultural o específicamente literario en las obras a las que nos hemos referido de Enrique Vila-Matas, César Aira o Juan Antonio Masoliver Ródenas.

\section{Autoficción, humor y «problema judío»}

El humor, en las tres formas aludidas, ayuda a relativizar muchas de las cuestiones que afectan a los autores de las obras que hemos mencionado, permitiéndoles distanciarse de sus existencias particulares. Como advierte David Roas (2009: 93) a propósito del trabajo de Alan Berliner, «con ello [su enfoque] adquiere una dimensión universal que permite al espectador compartir una vivencia que, tratada de otro modo, quizá hubiera sido excesivamente sentimental e intransferible». Dicho de otro modo, la autoficción, transida de humor, se aparta de lo real para volver a lo real, y poner de manifiesto el artificio que rige toda representación, incluida la del yo, mientras seguimos preguntándonos qué es un autor y cuáles son los vínculos que lo unen a su obra.

Teniendo en cuenta todos estos elementos, proponemos a continuación una lectura autoficcional de Operación Shylock (Operation Shylock: A Confession, 1993) y Desmontando a Harry (Deconstructing Harry, 1997), de Philip Roth y Woody Allen, respectivamente. Ambos autores han ido construyendo, a lo largo de toda su trayectoria, sendas máscaras -más o menos opacas, más o menos transparentes- a través de las cuales han proyectado sus personalidades, obsesiones, vivencias, en su obra literaria y cinematográfica, contribuyendo a generar, al mismo tiempo, una imagen pública cada vez más indisociable de los personajes que los han encarnado. Siguiendo nuestra conceptualización inicial, ambas obras pueden ser interpretadas como narraciones paradójicas: presentan elementos que orientan la recepción hacia la lectura autobiográfica (homonimia del autor, narrador y personaje, en el caso de Philip Roth; confluencia de rasgos caracterizadores entre el autor y su proyección textual, en el caso de Woody Allen); otros elementos, en cambio, orientan la recepción de la obra hacia la ficción, como la presencia «inverosímil» del doppelgänger, en Roth, o las continuas metalepsis, en Allen. Todo ello teñido de un humor que afecta tanto a la forma del relato (sometida a parodia) como a la autocaracterización del autor en tanto personaje.

Como subrayábamos al inicio de este trabajo, la paradoja intrínseca a esta clase de obras tiene como fin frustrar el horizonte de expectativas del lector. Tanto Operación Shylock como Desmontando a Harry recurren a la ironía paródica que consiste en asumir «los rasgos de un discurso 
concreto, bien mediante la repetición de un texto en un contexto diferente, bien mediante la alteración de dicho texto para otorgarle un sentido nuevo, o bien mediante la adopción de un modelo architextual para perturbarlo mediante el desequilibrio con el texto paródico producido» (Pueo, 2002: 73). En la medida en que dicho discurso forma parte de la enciclopedia del lector, «la alusión a dicho repertorio despierta en éste unas expectativas que se verán defraudadas en algún momento [...] por el nuevo texto, cuyo sentido se revela como algo distinto a lo esperado» (idem).

En Operación Shylock la ironía paródica surge ya desde los paratextos hasta extenderse al enunciado, como sucedía también en Los hechos, a través del contraste con un modelo architextual concreto, en este caso el del relato autobiográfico. En este sentido llaman la atención el subtítulo de la obra («Una confesión») y la dedicatoria «A Claire» (que el lector puede indentificar con la que fue pareja de Philip Roth durante diecisiete años, la actriz inglesa Claire Bloom), orientados hacia lo referencial. Pero sobre todo llama la atención la presencia de un prefacio del autor, en el que se apuntala de manera muy expresa la factualidad del texto. Roth asegura en él ceñirse a lo real y haber introducido tan sólo algunos mínimos cambios obligado por las circunstancias y con el fin de preservar la intimidad de algunas pocas personas:

Por razones legales he tenido que alterar algunos de los hechos narrados en este libro. Son cambios menores, referidos casi siempre a detalles de identificación y de emplazamiento; de escasa relevancia para la narración en su conjunto, y que en nada afectan su verosimilitud. [...] El libro relata, con toda exactitud de que he sido capaz, los sucesos reales que hube de vivir mediando el sexto decenio de mi edad, y que culminaron a principios de 1988, cuando me hice cargo de una operación de recogida de informes para los servicios secretos internacionales del gobierno israelí, llamados Mossad. (Roth, 1993: 11)

Lo cierto es que en los diez capítulos más el epílogo que componen la novela abundan los elementos referenciales, empezando por el nombre de su protagonista, que coincide con el del autor, junto con el de otras personas reales, como el escritor israelí Aharon Appelfeld, con el que Roth mantiene largas conversaciones, o el ucraniano emigrado a Cleveland John Ivan Demjanjuk, juzgado en Israel por haber asesinado en Treblinka a más de un millón de judíos. A ello hay que añadir las continuas llamadas a la propia existencia del autor, gracias a la presencia de aspectos de su vida abordados antes y después en otros libros suyos, además de confirmados en diversas entrevistas y declaraciones: aspectos de su vida que a veces, como corresponde a toda buena «confesión», son de índole muy personal, como la dependencia del Halcion, un medicamento contra el insomnio que, durante varios meses, provocó en Roth importantes desórdenes mentales y que a punto estuvo de llevarlo al suicidio. De igual modo, la marca tipográfica que indica que los nombres de determinados personajes han sido modificados genera en el lector esa sensación de estar leyendo sobre algo realmente acontecido. La temática del libro, centrada fundamentalmente en el «problema judío» y los conflictos de Israel con los palestinos y los países de su entorno, así como las abundantes reflexiones del narrador-autor (y de otros personajes) sobre estas cuestiones, potencian también la historicidad del texto.

No obstante, la referencialidad de la obra se ve muy pronto cuestionada a causa de los muchos elementos de la novela que resultan altamente improbables o directamente inverosímiles. Así, el 


\section{Ana Casas}

encuentro casi fantástico de Philip Roth con su doble en Israel: un hombre nacido en 1933 en Newart, Nueva Jersey, que se llama como él, tiene su mismo aspecto, su voz, su caligrafía, viste igual... y que en Jerusalén se hace pasar por el célebre escritor con el fin de difundir la teoría del diasporismo, que defiende el regreso de los judíos asquenazíes a Europa y tiene por objeto evitar un segundo Holocausto, esta vez perpretado por los árabes, así como restablecer el equilibrio en los territorios injustamente ocupados. Por otro lado, son demasiadas las coincidencias providenciales, los encuentros y desencuentros entre personajes, algunos de ellos de factura estrambótica o excéntrica, como Smilesburger, un judío americano que extiende cheques de un millón de dólares a favor de la causa del diasporismo y luego, cuando secuestra a Roth, revela ser un agente secreto del Mossad; o la explosiva Jinx, miembro de A.S.A., Anti Semitas Anónimos, en proceso de recuperación de su «dolencia». Del mismo modo, resulta poco creíble el hecho de que Roth decida no denunciar la existencia del impostor (con las implicaciones que ello podría tener para su imagen pública, además de comprometerlo muy seriamente, también en su integridad física) y acepte, en cambio, la confusión en torno a su identidad, pareciendo incluso gozar con ello: defiende con pasión el diasporismo ante el palestino George Ziad, alimentando los delirios de éste; se acuesta con Jinx, la amante del otro Roth; se cuela en la habitación de hotel que ocupa su doble para recabar pruebas, etc.

El juego de cambio de identidades - rocambolesco a veces y hasta grotesco- culmina en un ausente capítulo undécimo, tal y como se nos informa en el epílogo de la novela. Éste -que debía titularse precisamente «Operación Shylock»- narraría las -también poco creíbles- aventuras de Philip Roth como espía al servicio del Mossad. Una actividad que vendría a engrosar la lista de fraudes, simulaciones y simulacros que recorren la novela, empezando por la presencia del doble que usurpa la identidad de Roth, y del que nunca se conocerá su verdadera naturaleza (quién es realmente o para quién trabaja), y siguiendo con la extensa galería de personajes falsarios o, al menos, de identidad confusa o escurridiza: John Ivan Demjanjuk (asesino de judíos en Treblinka y/o trabajador, padre y esposo ejemplar en Cleveland), George Ziad (activista palestino y/o colaborador de los israelíes), Smilesburger (promotor del diasporismo y/o espía del Mossad), etc.

Irónicamente, al lector se le ocultan los detalles de lo sucedido en Atenas, donde Philip Roth tenía que ponerse en contacto con una serie de judíos acaudalados que financiaban entonces la OLP (también por motivos que se nos escapan). Es decir, se soslaya parte de los acontecimientos centrales que justificaban -tal y como se indicaba en el prefacio- la redacción de Operación Shylock, título que de manera elocuente apunta a los únicos hechos que no se narran, ya que justamente ese es el nombre de la operación de espionaje.

Se difuminan, de este modo, las fronteras entre lo referencial y lo ficcional: en el epílogo Philip Roth asegura haber optado por un tratamiento de los hechos «no novelesco», aunque admite también que, al terminar la redacción del undécimo capítulo y tras leer el manuscrito completo, «hallé en mi interior una extraña sensación de incertidumbre en lo tocante a la verosimilitud de mi libro» (415416). Finalmente, la obra que el lector tiene entre manos, ¿ se ciñe realmente a los acontecimientos tal y como el autor asegura en el prefacio y el narrador no deja de repetir en el epílogo, y ello pese a las 
inverosimilitudes señaladas? ¿O Roth ha decidido ficcionalizar los hechos, siguiendo las indicaciones de Smilesburger, de quien parte también la idea de mutilar la obra? El juego está servido... La nota al lector que cierra el libro no hace más que insistir en la propuesta contradictoria, paradójica, que se deriva de Operación Shylock:

Este libro es ficción. La conversación formal con Aharon Appelfeld recogida en los capítulos 3 y 4 se publicó previamente en The New York Times del 11 de marzo de 1988. Las transcripciones literales de la sesión matinal de 27 de enero de 1988 del Tribunal de Distrito de Jerusalén sirvieron para redactar las actuaciones ante el tribunal citadas en el capítulo 9. En todo lo demás, los nombres, personajes, lugares y acontecimientos son producto de la imaginación del autor o están utilizados de modo ficticio. Cualquier parecido con hechos, situaciones y personas reales, vivas o muertas, es mera coincidencia. Esta confesión es falsa. (Roth, 1993: 461)

En cuanto a Desmontando a Harry, el recurso que genera la ironía paródica se basa, como es habitual en la cinematografía de Allen, en la reescritura parcial de un texto anterior, en este caso Fresas salvajes (Smultronstället, 1957), de Ingmar Bergman. Así, los muchos elementos reflectantes que de algún modo identifican a Harry Block con el autor real -además del actor que encarna al protagonista, Woody Allen es el guionista y el director de la película- se ven cuestionados por la presencia del subtexto. Éste confiere a la historia un espesor «literario», autorreferencial, que contradice, o cuanto menos pone en cuarentena, los posibles paralelismos entre el personaje y la persona: las tribulaciones del artista, por ejemplo cuando se enfrenta a un bloqueo literario como ocurre aquí, o las difíciles relaciones con las mujeres, la academia o los compañeros de profesión, son aspectos que a menudo han sido documentados por quienes se han acercado a la biografía de Woody Allen. El «resorte creativo» de la intertextualidad (Roger, 2014: 237) invita a pensar en la obra como texto más que como representación veraz de la vida de un individuo ${ }^{8}$. De igual modo, la relación desdramatizada con el subtexto -la película de Bergman es definitivamente mucho más seria que la de Allen- subraya el modo irónico de la parodia: el rocambolesco viaje que emprende Harry, el escritor bloqueado, en compañía de una prostituta, de un amigo ocioso y de su hijo, al que ha «secuestrado», para asistir a su homenaje en la universidad que tiempo atrás lo había expulsado de sus aulas recuerda, por contraste, al viaje del médico jubilado Isak Borg (Victor Sjöström) que, acompañado de su nuera $\mathrm{y}$, durante algunos puntos del trayecto, de otros personajes que le van saliendo al paso, se dirige desde Estocolmo a Lund para recibir su doctorado honoris causa. El periplo de Isak - trufado de escenas oníricas y recuerdos del pasado- parece inspirar el de Harry, aunque las obsesiones de aquel (culpa, soledad, represión afectiva) tienen, en la película del neoyorquino, una modulación cómica de la que carece el film de Bergman. En ambos casos, sin embargo, los personajes se enfrentan a una verdad que al final les es revelada: la aceptación del amor como base de las relaciones interpersonales permite a Isak, casi al término de sus días, salir de su marasmo emocional; por su parte, refugiarse en la ficción, y elegirla como único modo de vida, permite a Harry superar su bloqueo creativo, además de poner algo de felicidad en su patética

\footnotetext{
${ }^{8}$ Cumple parecida función el simbolismo del nombre del protagonista: Harry Block (bloqueo en inglés).
} 
existencia. La película de Allen, por lo tanto, también incluye un homenaje «serio» a la obra de Bergman.

Por otro lado, la estructura de Desmontando a Harry en la que un relato marco -en gran medida el viaje en coche del protagonista- alberga un buen número de metarrelatos -algunas analepsis y sobre todo la escenificación de fragmentos de la novela de Harry, así como de cuentos que éste ha escrito o está en proceso de escribir- también colabora en desreferencializar la historia narrada. El recurso se muestra suficientemente artificioso como para despejar algunas dudas acerca de cualquier pretendido autobiografismo de la obra. El contenido de los relatos que remedan historias surgidas de la pluma de Harry, todas ellas de evidente inspiración autobiográfica -y las discusiones que en el nivel marco mantienen los personajes a propósito de éstas- ponen en evidencia el proceso de figuración, de «ficcionalización» al que el propio Harry somete sus vivencias y se somete él mismo cuando se proyecta textualmente en sus obras. Aunque el enfado de su cuñada Lucy (Judy Davis), al principio de la película, está más que justificado, al haber desvelado Harry en su novela la relación adúltera que mantuvo con ella en el pasado, la dramatización de uno de sus encuentros amorosos es tan exagerada y cómica que el espectador entiende - no la pobre Lucy, que no se conforma con ver su nombre transformado en Leslie ${ }^{9}$ - que los hechos no se narran exactamente como debieron de ocurrir: Ken (el alter ego de Harry encarnado por Richard Benjamin) y Leslie (Julia Louis-Dreyfus) haciendo el amor en la cocina en presencia de la abuela ciega, con la que conversan, en un divertido diálogo, tratando de disimular lo que allí está ocurriendo puede que tenga su parte de verdad pero no es la verdad. En el nivel metadiegético, por lo tanto, la hipérbole, la caricatura, el despropósito, caracterizan los textos de Harry, negando cualquier atisbo de transparencia artística; lo fantástico y lo onírico apuntan a esa misma dirección, en especial en el último de los metarrelatos, en el que Harry -que se presenta sin aparente disfraz y con su propio nombre- desciende a los infiernos con la intención de enfrentarse a su amigo Larry (Billy Crystal), transformado aquí en el mismo diablo, por haberle robado a su examante Fay (Elisabeth Sue). En este último texto Harry no necesita alterar su aspecto o cambiar su nombre en la ficción porque, en ese punto del film, ha entendido que, si bien en cierto modo todos sus personajes son él, éstos siempre acaban por tener vida propia, por ser otra cosa, como bien se encargan de sugerirnos las continuas incursiones metalépticas de aquéllos, cuando se desplazan del nivel metadiegético al diegético.

Por otro lado, los mecanismos narrativos del segundo nivel -las ficciones ideadas por Harryacaban por revelarse idénticos a los empleados en el primer nivel. El supuesto realismo de la historia marco se desvanece casi desde el principio gracias a la inclusión de escenas disparatadas, como el intento de asesinato de Harry por parte de Lucy, el hilarante viaje del protagonista o su detención en la universidad a manos de la policía, a lo que hay que añadir las continuas metalepsis, en especial al final de la película, cuando todos los personajes de Harry lo están esperando en casa para rendirle un

\footnotetext{
${ }^{9}$ Son varios los personajes que se enfrentan a Harry al identificarse con personajes de su novela: también se enfadan con él su hermana Doris (Caroline Aaron) y su exmujer Joan (Kristie Alley).
} 
homenaje. El desenlace -Harry sentándose a escribir, superado ya su bloqueo, acerca de «un tío que no sabe funcionar bien en la vida y que sólo funciona en el arte» ofrece una clave de lectura de la obra: «Todo el mundo conoce la misma verdad -dice Harry a propósito de su nuevo personaje de ficción-: nuestra vida depende de cómo elegimos distorsionarla».

Sobre Operación Shylock y Desmontando a Harry planea la idea de que cualquier comprensión de uno mismo está condenada al fracaso y de que es imposible alcanzar la verdad (Grimal, 1993: 184). Aunque en cierto momento el narrador de Operación Shylock se burla de lo que considera ya un lugar común: «Hasta los más crédulos desprecian hoy en día la noción de objetividad: la última teoría que se han tragado consiste en afirmar que nada puede expresarse con exactitud, como no sea la propia temperatura corporal; que todo es alegórico» (Roth, 1993: 246). Pero si representar lo real y representarse a uno mismo- resulta casi imposible, la ficción (la autoficción) sí permite, en cambio, vislumbrar otro tipo de verdad más íntima, hecha de equívocos y contradicciones. Ello resulta especialmente relevante a la luz de la identidad judía que tanto Philip Roth como Woody Allen escenifican a través de sus personajes y alter egos. Con relación a las conexiones entre la autoficción como forma artística y la obra de estos (y otros) creadores judíos podría apreciarse una confluencia de intereses, tal y como advierte Régine Robin, para quien la identidad judía de muchos autores no se reduce a una sola versión de sí misma: al contrario, heredera del «nomadismo», viene a «reforzar ejemplarmente la problemática de la diferencia, de la no coincidencia, de la travesía cultural e histórica de las lenguas, los territorios, los nombres propios, las polisemias y las evidencias de la identidad...»(Robin, 1997: 30). En este sentido, Roth y Allen desmontan la existencia de una identidad judía única o codificada. Sin renunciar al humor, Operación Shylock exhibe múltiples maneras de «ser judío» a través de los supervivientes del Holocausto, los judíos de la diáspora, los judíos americanos, los asimilados, los ortodoxos, los que regresaron a Israel, los judíos israelíes de origen semítico, los que no cuestionan el statu quo en Oriente Medio, los que sólo piensan en instalarse en Europa o en los Estados Unidos, los religiosos, los ateos. En la novela todos ellos debaten intensamente entre sí; defienden posturas, diversas, antagónicas, en las que a menudo proposiciones llenas de sentido común se mezclan con otras absurdas o delirantes. A esto hay que sumar la presencia de puntos de vista ofrecidos por gentiles, palestinos, antisemitas, además de los tradicionales prejuicios en torno a los judíos cuyo epítome podría ser Shylock, el despreciable usurero de El mercader de Venecia que da nombre a la novela ${ }^{10}$. El resultado es un mapa amplio y complejo, difícilmente esquematizable, de las distintas caras de la identidad judía. Una multiplicidad de la que no escapa el propio autor, fragmentado, despersonalizado a causa del Halcion y de sus intestabilidades internas, obligado a tener que mirarse en un doble tan descentrado como él.

Carente de la dimensión política de la novela de Roth, Desmontanto a Harry vierte su humor sobre determinadas tradiciones culturales de los judíos neoyorquinos. De los seis metarrelatos que

\footnotetext{
${ }^{10}$ El otro personaje estereotipado al que Roth se refiere en numerosas ocasiones es Moishe Pipik («Moisés Ombligo»), figura folklórica de la cultura judía que encarna la estupidez y cuyo nombre se usa para llamar a los niños pequeños cuando hacen algo mal. En distintos momentos de la novela, Roth no puede evitar identificarse con Moishe Pipik (Roth, 1993: 133, 175).
} 


\section{Ana Casas}

aparecen incrustrados en la narración marco, tres de ellos satirizan aspectos de la existencia judía del protagonista: el primero transforma literariamente la relación fracasada con Joan (Kirstie Allen/Demi Moore), la segunda mujer de Harry, debido, entre otros motivos, a los escrúpulos religiosos de ella, así como el distanciamiento de su hermana Doris (Caroline Aaron) por razones similares; el segundo carga las tintas de los estereotipos de la familia judía y reelabora el matrimonio de los padres de Harry, llamados en la ficción Dolly (Shifra Lerer) y Max (Hy Anzell), una pareja gritona pero bien avenida que no se pierde un Bar Mitzvah, hasta el momento en que se descubre que el hombre mató y devoró a su primera mujer; en el último relato, durante su descenso a los Infiernos, Harry se entrevista brevemente con su padre, al que acaba perdonando por su paternidad irresponsable, aunque éste rehusa abandonar el averno: «Soy judío: no creo en el cielo», le dice. Bajo la mirada de escepticismo radical de Harry/Allen, el retrato, en los tres casos, resulta hilarante. Para él, en definitiva, todas las religiones son la misma cosa: «Sólo son clubs. Son exclusivistas, [...] fomentan el concepto de los otros y de ese modo sabes muy bien a quién odiar».

\section{Conclusión: Desmontando al autor}

Las opiniones y dilemas de los protagonistas de Operación Shylock y Desmontando a Harry pueden atribuirse sin demasiadas dificultades a sus autores, por mucho que abunden las inverosimiludes, como en el caso de Roth, o las rupturas de la transparencia del relato, como en el caso de Allen. En este sentido, puede resultar pertinente la noción de «postura del autor», acuñada por Jerôme Meizoz (2007), según la cual los creadores ocupan una posición singular dentro del campo artístico, de manera que su «identidad» como tales creadores se ve continuamente subrayada por los media que, de distintas formas, promocionan o visibilizan sus obras y, a veces incluso, sus personalidades. En consecuencia, el papel público de los creadores, como les sucede a los mediáticos Roth y Allen, influye de manera determinante en la recepción que hacemos de sus textos y en las correspondencias que somos capaces de establecer entre la persona y su proyección ficcional, tanto como la imagen que ellos, en el ámbito de lo textual, se forjan de sí mismos libro a libro, película a película.

A partir de que Philip Roth publicara en 1969 el polémico El lamento de Portnoy no ha dejado de escribir relatos a través de los que ha ido cimentado su postura de autor: sus personajes parecen tener tanto de él (escritores, profesores, judíos de Newart, de vida sentimental atribulada) como él de sus personajes. No rehúye en Operación Shylock algunos aspectos poco agradables de su imagen pública en consonancia con algunas de las acusaciones de las que ha sido objeto a lo largo de los años (ser egocéntrico y antipático, creerse una celebridad de izquierdas, difamar el mundo judío o desear obtener fervientemente el Nobel), como tampoco lo hace Woody Allen en Desmontando a Harry cuando dota a su personaje de muchos de los rasgos atribuibles a su propia máscara ${ }^{11}$ (Alarcón, 2014: 108): nihilista, neurótico, solitario, incapaz de funcionar adecuadamente en la vida,

\footnotetext{
${ }^{11}$ El nombre de Woody Allen funciona en sí mismo como una máscara, puesto que, como es bien sabido, el nombre real del cineasta neoyorquino es Allan Stewart Konisberg.
} 
capaz únicamente de encontrar algo de serenidad en la ficción. Sin embargo, el autor, tal y como aparece representado en las obras de ambos, se presenta como un signo casi vacío, de referencialidad problemática. Fragmentado, ignorante de sí mismo, absurdo sin sus creaciones, el autor sólo puede desvelar a través de la ficción un proceso (vital y creativo) que abre interrogantes y apenas ofrece respuestas.

\section{Referencias bibliográficas}

AIRA, C. (2007): El congreso de literatura. Barcelona, Mondadori, 1997.

AlARCón, J. I. (2014): «Una autoficción sin identidad: Reflexiones en torno a la autoficción especular», en A. Casas, ed., El yo fabulado. Nuevas aproximaciones críticas a la autoficción. Madrid / Frankfurt, Iberoamericana / Vervuert, pp. 107-125.

Allen, W. (1997): Deconstructing Harry. Estados Unidos, Sweetland Films, 96 min.

Attal, Y. (2001): Ma femme est une actrice. Francia, Pathé, 95 min.

BALlaRT, P. (1994): Eironeia: figuración irónica en el discurso literario moderno. Barcelona, Sirmio.

BERGMAN, I. (1957): Smultronstället. Suecia, Svensk Filmindustri, 90 min.

BeltrÁn AlmeríA, L. (2002): La imaginación literaria. La seriedad y la risa en la literatura occidental. Barcelona, Montesinos.

BRUNI-TEDESCHI, V. (2003): Il est plus facile pour un chameau. Francia, Gemini Films / Interlinea Films, 110 min.

— (2007): Actrices. Francia, Canal+ / Centre National de la Cinématographie (CNC) / Fidélité Productions / Virtual Films / Wild Bunch, 107 min.

CASAs, A. (2012): «El simulacro del yo: la autoficción en la narrativa actual», en A. Casas, ed., $L a$ autoficción. Reflexiones teóricas. Madrid, Arco Libros, pp. 9-42.

Colonna, V. (1989): L'autofiction. Essai sur la fictionalisation de soi en littérature. Tesis de doctorado, École des hautes études en Sciences Sociales, Lille. En https://tel.archivesouvertes.fr/tel-00006609/document (última consulta, 17-01-2015).

DARRIEUSSECQ, M. (1996): «La autoficción, un género poco serio». Trad. de Enric Sullà. En A. CASAS, ed., La autoficción. Reflexiones teóricas. Madrid, Arco Libros, 2012, pp. 65-82.

Doubrovsky, S. (1977): Fils. París, Galilée.

GRIMAL, C. (1993): «Philip Roth: L’espace autobiographique», Autofictions \& Cie. Ritm, 6, pp. 183192.

HerRera ZAMUdio, L. E. (2007): La autoficción en el cine. Una propuesta de definición basada en el modo analítico de Vincent Colonna. Tesis de doctorado, Universidad Autónoma de Madrid, en https://repositorio.uam.es/handle/10486/1680 (última consulta, 17-01-2015).

Hutcheon, L. (1985): A Theory of Parody. The Teachings of Twentieth-Century Art Forms. Nueva York / Londres, Methuen. 
(1988): A Poetics of Postmodernism: History, Theory, Fiction. Nueva York / Londres, Routledge, 2004.

JONZE, S. (2002): Adaptation. Estados Unidos, Columbia Pictures / Intermedia, 114 min.

Kaufman, C. (2008): Synecdoque, New York. Estados Unidos, Likely Story / Sidney Kimmel Entertainment, $124 \mathrm{~min}$.

MALDERA SATTORI, S. (2010): Charlie Kaufman y la organización colosal del vacío. Tesis de Fin de Máster, Universitat Autònoma de Barcelona.

MASOliver RódenAs, J. A. (1988): Retiro lo escrito. Barcelona, Anagrama.

- (1991): Beatriz Miami. Barcelona, Anagrama.

- (2001): La puerta del inglés. Barcelona, El Acantilado.

- (2014): El ciego en la ventana. Barcelona, El Acantilado.

MeIzOZ, J. (2007): Postures littéraires. Mises en scène modernes de l'auteur. Ginebra, Slatkine.

Moretti, N. (1993): Caro diario. Italia, Sacher Film / BanFilm / La Sept Cinéma, 96 min. (1998): Aprile. Italia-Francia, Sacher Film / Bac Films / Le Studio Canal + / La Sept Cinema, 78 min.

Pozuelo Yvancos, J. M. (2005): De la autobiografía. Teoría y estilos. Barcelona, Crítica.

- (2010): Figuraciones del yo en la narrativa. Javier Marías y E. Vila-Matas. Valladolid, Cátedra Miguel Delibes.

Premat, J. (2009): Héroes sin atributos. Figuras de autor en la literatura argentina. Buenos Aires, Fondo de Cultura Económica.

PUEO, J. C. (2002): Los reflejos del juego (Una teoría de la parodia). Valencia, Tirant lo Blanc.

Quílez EsTEVE, L. (2009): «Cuando el documentalista se ríe de sí mismo. La estética del fracaso y el documental performativo en Avi Mograbu, Ross McElwee y Alan Berliner», en E. Oroz y G. de Pedro Amatria, eds., La risa oblicua. Tangentes, paralelismos e intersecciones entre documental y humor. Madrid, Ayuntamiento de Madrid, pp. 117-133.

RoAs, D. (2009): «Humores posmodernos. Hacia una epistemología de la risa en la (supuesta) Era del Vacío», en E. Oroz y G. de Pedro Amatria, eds., La risa oblicua. Tangentes, paralelismos e intersecciones entre documental y humor. Madrid, Ayuntamiento de Madrid, pp. 75-94.

RoBIn, R. (1997): Le Golem de l'écriture au Cybersoi. Montreal, XYZ.

ROGER, J. (2014): «Literatura e intertextualidad: Varia imaginación y Desarticulaciones de Sylvia Molloy», en A. Casas, ed., El yo fabulado. Nuevas aproximaciones críticas a la autoficción. Madrid / Frankfurt, Iberoamericana / Vervuert, pp. 227-245.

Roth, P. (1993): Operación Shylock. Madrid, Alfaguara, 1996.

- (1988): Los hechos. Madrid, Alfaguara, 2008.

VARA FERRERO, N. (2014): «Formulaciones paródicas al servicio de la autoficción. La propuesta de Enrique Vila-Matas», en A. Casas, ed., El yo fabulado. Nuevas aproximaciones críticas a la autoficción. Madrid / Frankfurt, Iberoamericana / Vervuert, pp. 209-225.

Vila-Matas, E. (2003): París no se acaba nunca. Barcelona, Anagrama. 